\title{
AMICUS CURIAE, MODELO PROCESSUAL DEMOCRÁTICO E O NOVO CÓDIGO DE PROCESSO CIVIL ${ }^{1}$
}

\section{AMICUS CURIAE, CONSTITUTIONAL PROCESS MODEL AND THE NEW CODE OF CIVIL PROCEDURE}

Mônica Bonetti Couto

Professora Permanente do Programa de Mestrado em Direito da Universidade Nove de Julho - São Paulo. Mestre e Doutora pela Pontifícia Universidade Católica de São Paulo PUC/SP. Especialista em Direito Processual Civil pela Universidade Federal do Paraná - UFPR. Advogada em São Paulo/SP. monicabonetticouto@terra.com.br

Guilherme Amorim Campos da Silva Professor Permanente do Programa de Mestrado em Direito da Universidade Nove de Julho - São Paulo. Mestre e Doutor pela Pontifícia Universidade Católica de São Paulo PUC/SP. Advogado em São Paulo/SP e Brasília/DF. ga@ rnaves.com.br

RESUMO: O presente estudo objetiva investigar a disciplina do amicus curiae no sistema jurídico brasileiro, em particular no Novo Código de Processo Civil. Destaca-se a relevância de sua atuação para a ampliação da participação no processo, dentro de um cenário democrático que se instalou no país após o advento da Constituição de 1988. O escopo deste estudo consiste em averiguar se a aplicação do amicus curiae nos processos em geral, tal como prevê o Novo CPC, contribui efetivamente para a consolidação do modelo processual democrático, permitindo o enriquecimento do debate e da construção da decisão judicial o que, por consequência, implica na efetivação das garantias inerentes ao Estado Democrático de Direito.

\footnotetext{
${ }^{1}$ Artigo recebido em 26/06/2017 e aprovado em 21/11/2017.
} 
PALAVRAS-CHAVE: Amicus Curiae; Direitos e Garantias Individuais; Novo Código de Processo Civil; Modelo Constitucional de Processo; Processo Democrático.

\begin{abstract}
The present paper aims to investigate the amicus curiae institute in the Brazilian legal system, pointing in the New Code of Civil Procedure. Highlight the relevance of its activities to the expansion of the participation in the process in a democracy after the advent of the 1988 Constitution. The scope of this study is to investigate whether the application of the amicus curiae in the process bulge in general contributes effectively to the consolidation of the democratic process model, allowing the active participation of society in all the instances of judgment, allowing the enrichment of the discussion judicial and valuing the Democratic State of Law, in matters of great social interest and collective relevance.
\end{abstract}

KEYWORDS: Amicus Curiae; Individual Rights and Guarantees; New Code of Civil Procedure; Constitutional Process Model; Democratic Process.

SUMÁRIO: Introdução. 1. O (novo) modelo constitucional de processo civil: a necessidade de um modelo de processo verdadeiramente democrático. 2. A figura do amicus curiae no direito brasileiro: contornos gerais. 3. O amicus no Novo Código de Processo Civil (Lei no 13.105/15). 4. O amicus curiae, o Novo CPC e a efetivação do Estado Democrático de Direito. Conclusão. Referências Bibliográficas.

\title{
INTRODUÇÃO
}

O Novo Código de Processo Civil surgiu, dentre outras relevantes razões, da premente necessidade de conferir-se à atividade jurisdicional uma maior legitimidade democrática, capaz de coadunar o processo judicial aos valores e garantias previstos na Constituição Federal. O fenômeno da constitucionalização do processo civil, iniciado com a Constituição de 1988, teve, portanto, seu ápice com a promulgação do Novo CPC, no qual, de forma definitiva, objetivou-se a construção de um ambiente comparticipativo, onde as partes atuam em conjunto na construção do processo e das decisões judiciais. 
Revista Eletrônica de Direito Processual - REDP.

Rio de Janeiro. Ano 11. Volume 18. Número 3. Setembro a Dezembro de 2017

Periódico Quadrimestral da Pós-Graduação Stricto Sensu em Direito Processual da UERJ

Patrono: José Carlos Barbosa Moreira. ISSN 1982-7636. pp. 256-279

www.redp.uerj.br

Harmonizando o texto da lei processual civil com os ideais incutidos na

Constituição Federal, foi perceptível uma preocupação maior em determinar garantias de ordem processual capazes de propiciar a efetivação da ampla gama de direitos e liberdades constitucionais, como medida lógica necessária para uma completa fruição dos direitos fundamentais por parte dos cidadãos.

O Novo CPC, em matéria de intervenção de terceiros, promoveu uma série de inovações, como, por exemplo, a eliminação da nomeação à autoria, a regulamentação do incidente da desconsideração da personalidade jurídica, além de novidades circunstanciais no âmbito da denunciação da lide e da assistência. Contudo, dentre todas as novidades introduzidas pelo legislador ordinário, destaca-se a normatização do amicus curiae no bojo do processo civil subjetivo, objeto do presente estudo.

Conhecida majoritariamente como o "amigo da corte", a figura do amicus curiae pode ser definida como uma pessoa (física ou jurídica) capaz de auxiliar e colaborar com o juiz na compreensão e especificidades de questões de alta relevância social ou política.

É fato amplamente reconhecido que a demandas atuais encontram-se demasiadamente complexas, envolvendo aspectos não só jurídicos, como também políticos, econômicos e sociais, impedindo que o magistrado decida o caso com base, exclusivamente, no que determina a letra da lei, recorrendo o juiz a normas de caráter aberto, bem como a princípios, doutrina e jurisprudência, em uma grande atividade interpretativa que não se restringe apenas a aplicação "fria" da lei ao caso concreto.

Para cumprir tal mister, este estudo está estruturado em quatro seções. Na primeira delas, examinar-se-ão os novos paradigmas do processo civil, relativamente ao chamado modelo constitucional democrático de processo. Mais adiante, far-se-á uma contextualização inicial acerca dos contornos do instituto, já há muito previsto em esparsas leis brasileiras, sobretudo no âmbito do controle de constitucionalidade. Neste sentido, realizar-se-á breve análise da aplicação da figura do amicus curiae no bojo do processo constitucional objetivo, explorando suas vantagens no aprimoramento qualitativo do debate processual. Na terceira seção, traçar-se-á um panorama geral das inovações trazidas pelo Código de Processo Civil, relativamente à disciplina que o instituto recebeu. Por fim, o último item é dedicado procurar-se-á averiguar em que medida a previsão do instituto, no Novo CPC, contribui efetivamente para a consolidação do modelo processual democrático à complexidade das demandas da sociedade atual. 


\section{O (NOVO) MODELO CONSTITUCIONAL DE PROCESSO CIVIL: A NECESSIDADE DE UM MODELO DE PROCESSO VERDADEIRAMENTE DEMOCRÁTICO}

A Constituição da República Federativa do Brasil de 1988 inaugurou uma nova fase do constitucionalismo com o advento do Estado Democrático de Direito, pautando-se em dois pilares primordiais, quais sejam, a consolidação da democracia e a garantia dos direitos fundamentais no sistema jurídico brasileiro.

A partir da instituição deste novo paradigma, a matriz principiológica contida no texto constitucional ganhou papel de destaque, funcionando, por assim dizer, como centro de normatividade de todo o ordenamento jurídico e determinando valores sociaisdemocráticos que devem conformar a atuação do Estado, sempre afetada à persecução e garantia dos direitos fundamentais.

Nesse sentido, a partir do modelo constitucional contemporâneo, os valores e postulados constitucionais passaram a permear definitivamente as mais diferentes searas do sistema jurídico brasileiro. Dessa ordem, vislumbrou-se uma maior aproximação entre processo e Constituição ${ }^{2}$, que culminou no surgimento de um novo modelo processual, chamado de processo civil constitucional (ou Direito Processual Constitucional), no qual a jurisdição estatal, e a formação do processo em si, restam conformadas por princípios e regras inspirados pela supremacia do texto constitucional, de modo a assegurar os direitos e garantias fundamentais do Estado Democrático de Direito no bojo da relação processual. 3

Sobre o tema, afirma Artur Torres:

Reconhece-se hodiernamente a existência de um modelo constitucional de processo comprometido com a concreção dos direitos fundamentais. Tal responsabilidade não mais se limita a instrumentalizar a proteção oriunda do plano material

\footnotetext{
${ }^{2}$ Não se pode dizer que essa aproximação seja uma novidade pós Constituição de 1988. Ver, a respeito, COUTO, Mônica Bonetti; MEYER-PFLUG; Samantha Meyer. Processo Civil e Constituição: uma (Re) aproximação necessária. Processo e Jurisdição. Organização: CONPEDI/UFF. Coordenadores: Vladmir Oliveira da Silveira; Aires José Rover. Florianópolis, FUNJAB, 2012, pp. 411-433. <http://www.publicadireito.com.br/artigos/?cod=173f0f6bb0ee97cf >. Acesso em 25.05.2017.

3 Sobre a relação entre processo e democracia, consulte-se o excelente texto de SILVA, Fernando Laércio Alves da. Processo Constitucional: o processo como locus devido para o exercício da democracia. Revista Eletrônica de Direito Processual. V. 6, n. 16, jul/dez.2015.
} 
Revista Eletrônica de Direito Processual - REDP.

Rio de Janeiro. Ano 11. Volume 18. Número 3. Setembro a Dezembro de 2017

Periódico Quadrimestral da Pós-Graduação Stricto Sensu em Direito Processual da UERJ

Patrono: José Carlos Barbosa Moreira. ISSN 1982-7636. pp. 256-279

www.redp.uerj.br

em sentido estrito. Segundo concepção que adotamos, um passo à frente foi dado. Admite-se contemporaneamente a existência de um rol de direitos (igualmente fundamentais) que, ainda que tenham valia apenas no e em razão do processo, compõem o núcleo das posições jurídicas mínimas do cidadão, devendo, em tudo e sempre, orientar interpretações, bem como a regulamentação de qualquer regime processual, seja ele de que natureza for. ${ }^{4}$

O sistema de direito processual civil vigente à época da Constituição de 1988, esculpido no bojo da ditadura militar, muito sofreu diante de reformas que visavam sua adequação ao Estado Democrático de Direito, o que acabou por comprometer a própria coesão normativa do sistema. Logo, era latente a necessidade de que o Código de Processo Civil de 1973 desse lugar a um novo regramento, mais moderno, menos burocrático e efetivamente democrático, alinhado a todas as perspectivas constitucionais alcançadas.

Foi precisamente nesse ambiente que emergiu o Novo Código de Processo Civil (Lei $\mathrm{n}^{\mathrm{o}}$ 13.105/15), pautado em um processo civil democrático e constitucional, declarando, já de início, o método que haverá de ser utilizado na leitura, interpretação e aplicação das regras ali previstas $\left(\operatorname{art} .1^{\circ}\right) .{ }^{5}{ }^{6}$

É dizer, o que se coloca, neste contexto, é que os princípios e garantias previstos e advindos da Constituição Federal sejam vetores de aplicação do direito processual civil, ditando "padrões políticos para a vida" deste.

\footnotetext{
${ }^{4}$ TORRES, Artur. Constituição, Processo e Contemporaneidade: o modelo constitucional do processo brasileiro. Temas Atuais de Processo Civil, v. 1, p. 44-81, 2011. Disponível em <Br/edicoes-anteriores/48-v1-n2-agosto-de-2011/132-constituição-processo-e-contemporaneidade-o-modelo-constitucional-do-processobrasileiro>. Acesso em 26 jan. 2017.

5 “Art. $1^{\circ}$. O processo civil será ordenado, disciplinado e interpretado conforme os valores e princípios fundamentais estabelecidos na Constituição da República Federativa do Brasil, observando-se as disposições deste Código."

${ }^{6}$ Ver, sobre o tema: MENDES, Aluisio Gonçaves de Castro; SILVA, Larrisa Clare Pochmann. Normas Fundamentais do Código de Processo Civil de 2015: breves reflexões. Revista Eletrônica de Direito Processual. V. 17, n. 2, jul/dez.2016.

${ }^{7}$ DINAMARCO, Cândido Rangel; LOPES, Bruno Vasconcelos Carrilho Lopes, Teoria Geral do Novo Processo Civil, 2. ed. Malheiros: São Paulo, 2017, p. 53. Segundo referidos autores "Ao se conceber e interpretar os institutos de direito processual, portanto, os princípios constitucionais devem sempre ser tomados como superiores premissas de todo o sistema, ponderando-se a importância concreta de cada um e buscando uma solução que, na medida do possível, confira a máxima efetividade a todos eles." (op. cit, mesma página). E, mais adiante, prossegue: "A Constituição formula princípios, oferece garantias e impõe exigências em relação ao sistema processual (...). Mediante esse conjunto de disposições a Constituição Federal quer afeiçoar o processo a si mesma, de modo que ele reflita, em menor escala, o que em escala maior está à base do próprio Estado de direito (legalidade, devido processo legal, participação em contraditório)." (op. cit., p. 54).
} 
Revista Eletrônica de Direito Processual - REDP.

Rio de Janeiro. Ano 11. Volume 18. Número 3. Setembro a Dezembro de 2017

Periódico Quadrimestral da Pós-Graduação Stricto Sensu em Direito Processual da UERJ

Patrono: José Carlos Barbosa Moreira. ISSN 1982-7636. pp. 256-279

www.redp.uerj.br

A base principiológica contida na configuração do atual Código de Processo Civil preocupou-se, do ponto de vista democrático, com um processo centrado em premissas comparticipativas e policêntricas, de modo a resgatar a participação da sociedade no debate processual em contraposição ao protagonismo judicial.

De fato, impõe-se uma releitura do processo civil e do papel assumido por seus sujeitos, conformando-os a essa visão democrática. Isso não se limita apenas à colaboração das partes entre si (art. 6. ${ }^{\circ} \mathrm{NCPC}^{8}$ ), em um modelo designado por comparticipativo ${ }^{9}$, posto que há uma evidente ampliação do papel do juiz, ao longo de todo o desenvolvimento do processo e da construção da decisão judicial. ${ }^{10}$

A partir da análise do processo fundamentado em premissas policêntricas e comparticipativas, vislumbra-se um ambiente coletivo propício à ampla comunicação das partes envolvidas, conscientes de sua responsabilidade na formação do convencimento do julgador. Ademais, instaura-se um espaço democrático, no qual a clássica faceta adversarial do processo, dá lugar ao equilíbrio intersubjetivo, ancorado nos princípios processuais constitucionais. ${ }^{11}$

Isso porque, diante da nova estrutura evidenciada pelo Código de Processo Civil atual, é possível enxergar a necessidade de um processo verdadeiramente democrático, pautado na racionalidade do diálogo, com a participação ativa de todos os sujeitos processuais na formação de uma decisão judicial justa. É imperioso que se afaste a concepção "privatista" de processo, de modo que todos os instrumentos que incentivem a participação social, como forma de consolidação do postulado democrático constitucionalmente determinado, devam ser incentivados pelo ordenamento jurídico.

É nesse cenário que se insere o amicus curiae, objeto do presente artigo, instituto jurídico capaz de pluralizar o debate jurisdicional, contribuindo para uma maior qualidade das decisões, na medida em que viabiliza a verdadeira participação da sociedade no exercício da jurisdição estatal. Deste modo, seus contornos gerais e seu tratamento frente ao Código de Processo Civil de 2015 serão a seguir estudados, de modo a perceber sua

\footnotetext{
8 “Art. $6^{\circ}$. Todos os sujeitos do processo devem cooperar entre si para que se obtenha, em tempo razoável, decisão de mérito justa e efetiva."

9 THEODORO JÚNIOR, Humberto; NUNES, Dierle; BAHIA, Alexandre de Melo Franco; PEDRON, Flávio Quinaud. Novo CPC - Fundamentos e sistematização. Rio de Janeiro: Forense, 2015, p. 54.

${ }_{10}$ Cf. Arts. $9^{\circ}, 10,77-81,190-191$.

11 NUNES, Dierle José Coelho. Processo Jurisdicional Democrático. $1^{\text {a }}$ ed. Curitiba: Juruá, 2012, p. 212.
} 
Revista Eletrônica de Direito Processual - REDP.

Rio de Janeiro. Ano 11. Volume 18. Número 3. Setembro a Dezembro de 2017

Periódico Quadrimestral da Pós-Graduação Stricto Sensu em Direito Processual da UERJ

Patrono: José Carlos Barbosa Moreira. ISSN 1982-7636. pp. 256-279

www.redp.uerj.br

crescente importância, uma vez que sua aplicação foi ampliada para todos as modalidades

de procedimentos judiciais.

\section{A FIGURA DO AMICUS CURIAE NO DIREITO BRASILEIRO: CONTORNOS GERAIS}

Surgido no direito norte-americano, a figura do amicus curiae (em tradução literal "amigo da corte") tem origem democrática, uma vez que permite a manifestação sujeitos estranhos ao processo, por provocação judicial ou por livre iniciativa. Esses sujeitos ${ }^{12}{ }_{-}{ }^{13}$ passam, então, a integrar a demanda, a fim de contribuir e incrementar objetivamente teses jurídicas que podem afetar a sociedade como um todo, podendo, igualmente, oferecer ao juízo elementos indispensáveis ao julgamento da causa. Essa figura tem uma função histórica de chamar a atenção da Corte para fatos ou circunstâncias importantes que poderiam não ser notados sem sua atuação.

Oportuno ressaltar que uma figura bastante assemelhada ao amicus curiae já se encontrava prevista no ordenamento brasileiro desde 1965. A Lei no 4.726/65, que tratava dos "Serviços de Registro de Comércio e Atividades afins" - atualmente revogada -, já previa figura análoga no parágrafo $3 .^{\circ}$ de seu artigo 50. Mais adiante, Lei nº.385/76, nos

12 A natureza jurídica dessa figura sempre foi deveras controversa. Há quem o repute um terceiro propriamente dito, enquadrando-o dentro do quadro de intervenção de terceiros de nosso sistema, ora como assistente, ora como terceiro prejudicado. Há quem, como nós, entenda que se trate de figura sui generis, que, conquanto possua alguns traços que o assemelhem, não é assistente, nem terceiro prejudicado. A Lei $\mathrm{n}^{\circ}$ 9.868/99 deixou ainda mais evidente a distinção desse instituto (amicus curiae) da intervenção de terceiros, essa textual e expressamente vedada no procedimento de controle de constitucionalidade (Cf. Lei $\mathrm{n}^{\circ}$ 9.868/99, art. $7^{\circ}$, caput ("Não se admitirá intervenção de terceiros no processo de ação direta de inconstitucionalidade.”). Essa diferenciação entre as figuras processuais, como já explicitava o Ministro Celso de Mello antes do advento da Lei $\mathrm{n}^{\circ}$ 9.868/99, decorre do fato de o amicus curiae não assumir condição jurídica de sujeito do processo de controle normativo abstrato, sendo apenas capaz de veicular informações ou subsídios destinados a esclarecer algum ponto ou questão relativo àquele debate. Voto do min. Celso de Mello no julgamento de Agravo Regimental na ADI 748-4Seguindo outro caminho - e a nosso ver, equivocadamente -, o Novo Código de Processo Civil, ao disciplinar o tema, colocou-o "dentro" do Título III, que trata da intervenção de terceiros, ao lado dos institutos/figuras da assistência, da denunciação da lide, do chamamento ao processo e do incidente de desconsideração da personalidade jurídica (vide, mais adiante, o tópico especialmente destinado ao assunto).

${ }^{13}$ É igualmente polêmica a natureza de sua atuação pois, em algumas situações - e isso ocorre de maneira inadequada, ou, ao menos, em evidente desvirtuamento do instituto -, o amicus curiae atua "em favor" de uma das teses e, portanto, colaborando com uma das partes. Adhemar Ferreira Maciel já reconhecia essa situação, ao aduzir: "o terceiro que comparece ao processo alheio vem, na realidade, mais com o intuito de ajudar uma daspartes do que mesmo trazer esclarecimentos ao tribunal ('Amicus Curiae': um instituto democrático, Revista de Informação Legislativa. Brasília, ano 38, n. 153, jan./mar.2002, p. 7). Ver, igualmente, sobre o tema: MEDINA, Damares. Amicus Curiae: Amigo da Corte ou Amigo da Parte? São Paulo: Saraiva, 2010. 
Revista Eletrônica de Direito Processual - REDP.

Rio de Janeiro. Ano 11. Volume 18. Número 3. Setembro a Dezembro de 2017

Periódico Quadrimestral da Pós-Graduação Stricto Sensu em Direito Processual da UERJ

Patrono: José Carlos Barbosa Moreira. ISSN 1982-7636. pp. 256-279

www.redp.uerj.br

termos de seu artigo 31, dispunha sobre a legitimidade da Comissão de Valores Mobiliários (CVM) para interposição de recursos. No mesmo sentido, a Lei no 8.884/94 previa a intervenção do Conselho Administrativo de Defesa Econômica (CADE), como assistente, desde que intimado, sendo essa previsão mantida pela Lei 12.259/2011 que revogou a lei anterior (art. 118). ${ }^{14}$

Importa ter presente que a Constituição de 1988 trouxe profundas alterações nos contornos do controle abstrato de constitucionalidade, inovando na criação da Arguição de Descumprimento de Preceito Fundamental e da Ação Declaratória de Constitucionalidade (trazida efetivamente pela Emenda Constitucional nº 03/93). Mas foi apenas em 1999, após sólida e madura jurisprudência do egrégio Supremo Tribunal Federal, que essas ações, juntamente com a Ação Direta de Inconstitucionalidade, foram regulamentadas. ${ }^{15}$

A Lei $n^{\circ}$ 9.868/99, que dispõe sobre o processo e julgamento das Ações de Inconstitucionalidade, positivou de forma definitiva a figura do amicus curiae, permitindo a manifestação de "outros órgãos ou entidades"16, diferenciando essa figura daquelas inerentes à intervenção de terceiros, vedada expressamente no procedimento de controle de constitucionalidade, como já dito. ${ }^{17}$ De igual sorte, no mesmo ano, a Lei da ADPF $\left(\mathrm{n}^{\circ}\right.$ 9.882/99) previu que: “Art. $6^{\circ}(\ldots) . \S 1^{\circ}$ Se entender necessário, poderá o relator ouvir as partes nos processos que ensejaram a arguição, requisitar informações adicionais, designar perito ou comissão de peritos para que emita parecer sobre a questão, ou ainda, fixar data para declarações, em audiência pública, de pessoas com experiência e autoridade na matéria." 18

Em emblemática manifestação, referendou o Plenário do Supremo Tribunal Federal, sob a relatoria do Ministro Edson Fachin, que "A interação dialogal entre o STF e pessoas naturais ou jurídicas, órgãos ou entidades especializadas, que se apresentem como amigos da Corte, tem um potencial epistêmico de apresentar diferentes pontos de vista,

\footnotetext{
${ }^{14}$ Ver, sobre o tema: DIDIER JÚNIOR, Fredie Didier. Recurso de terceiro: juízo de admissibilidade. 2. ed. São Paulo: RT, 2005.

${ }^{15}$ Cf. BUENO, Cassio Scarpinella. Amicus Curiae no Processo Civil Brasileiro - um terceiro enigmático. 3. ed. São Paulo: Saraiva, 2012, p. 130.

${ }^{16}$ Cf. Lei $n^{\circ} 9.868 / 99$, art. $7^{\circ}, \S 2^{\circ}$, onde se lê, in verbis: "O relator, considerando a relevância da matéria e a representatividade dos postulantes, poderá, por despacho irrecorrível, admitir, observado o prazo fixado no parágrafo anterior, a manifestação de outros órgãos ou entidades."

${ }^{17}$ Vide nota 8, supra.

18 Mais recentemente, outras legislações passaram a prever a participação de figura que em muito se aproxima a do amicus: Lei dos Juizados Especiais Federais (Lei $n^{\circ} 10.259 / 2001$, art. 14, $\S 7^{\circ}$ ); Lei que regulamentou a Súmula Vinculante (Lei n ${ }^{\circ} 11.417 / 2006$, art. $3^{\circ}, \S 2^{\circ}$ ); CLT, art. 896-C, $\S 8^{\circ}$.
} 
Revista Eletrônica de Direito Processual - REDP.

Rio de Janeiro. Ano 11. Volume 18. Número 3. Setembro a Dezembro de 2017

Periódico Quadrimestral da Pós-Graduação Stricto Sensu em Direito Processual da UERJ

Patrono: José Carlos Barbosa Moreira. ISSN 1982-7636. pp. 256-279

www.redp.uerj.br

interesses, aspectos e elementos nem sempre alcançados, vistos ou ouvidos pelo Tribunal diretamente da controvérsia entre as partes em sentido formal, possibilitando, assim, decisões melhores e também mais legítimas do ponto de vista do Estado Democrático de Direito." 19

Seguindo esse mesmo norte, é a lição de Fredie Didier Jr, ao aduzir que o "amicus é o auxiliar do juízo, com a finalidade de aprimorar ainda mais as decisões proferidas pelo Poder Judiciário", pois "reconhece-se que o magistrado não detém, por vezes, conhecimentos necessários e suficientes para a prestação da melhor e mais adequada tutela jurisdicional". 20

Este então novel instituto não integra aos interesses simplesmente eventuais ou em qualquer causa em que as partes litigam, mas, sim, ao próprio exercício da cidadania e à preservação dos princípios e, muito particularmente, no que nos interessa, à ordem constitucional. Não deve, portanto, patrocinar interesses de uma ou de outra parte, mas colaborar com a Justiça. Como reconheceu recentemente o próprio STF, "embora possa deter algum interesse no desfecho da demanda, não se vincula processualmente ao resultado do seu julgamento. É que sua participação no processo ocorre e se justifica, não como defensor de interesses próprios, mas como agente habilitado a agregar subsídios que possam contribuir para a qualificação da decisão a ser tomada pelo Tribunal. A presença de amicus curiae no processo se dá, portanto, em benefício da jurisdição, não configurando, consequentemente, um direito subjetivo processual do interessado." 21

${ }^{19}$ O julgado acima referido tem a seguinte ementa: "AGRAVO REGIMENTAL EM AÇÃO DIRETA DE INCONSTITUCIONALIDADE. RESOLUÇÃO No 13/2012 DO SENADO FEDERAL. PEDIDO DE INGRESSO COMO AMICUS CURIAEINDEFERIDO. AUSÊNCIA DE CONTRIBUIÇÃO ESPECÍFICA. 1. A interação dialogal entre o STF e pessoas naturais ou jurídicas, órgãos ou entidades especializadas, que se apresentem como amigos da Corte, tem um potencial epistêmico de apresentar diferentes pontos de vista, interesses, aspectos e elementos nem sempre alcançados, vistos ou ouvidos pelo Tribunal diretamente da controvérsia entre as partes em sentido formal, possibilitando, assim, decisões melhores e também mais legítimas do ponto de vista do Estado Democrático de Direito. 2. Conforme os arts. $7^{\circ}$, $\S 2^{\circ}$, da Lei 9.868/1999 e 138 do CPC/15, os critérios para admissão de entidades como amicus curiae são a relevância da matéria, especificidade do tema ou repercussão social da controvérsia, assim como a representatividade adequada do pretendente. 3. Agravo regimental a que se nega provimento." (ADI 4858 AgR/DF, Relator(a) Min. Edson Fachin, Julgamento: 24/03/2017, Órgão Julgador: Tribunal Pleno, Publicação: DJe-066, Divulgado 31-03-2017, Publicado: 03-04-2017).

${ }_{20}$ JÚNIOR, Fredie Didier. Possibilidade de Sustentação Oral do Amicus Curiae. Revista Dialética de Direito Processual 8:2003.

${ }^{21}$ ADI 3460 ED/DF, Relator(a): Min. Teori Zavascki, Julgamento: 12/02/2015, Órgão Julgador: Tribunal Pleno, DJe-047, Divulgado em 11-03-2015, Publicado em 12-03-2015. 
Revista Eletrônica de Direito Processual - REDP.

Rio de Janeiro. Ano 11. Volume 18. Número 3. Setembro a Dezembro de 2017

Periódico Quadrimestral da Pós-Graduação Stricto Sensu em Direito Processual da UERJ

Patrono: José Carlos Barbosa Moreira. ISSN 1982-7636. pp. 256-279

www.redp.uerj.br

O propósito da existência da figura do amicus curiae consiste, portanto, na

pluralização do debate constitucional, permitindo ao Supremo Tribunal Federal dispor de todos os elementos informativos possíveis e necessários à resolução da questão ali posta.

Nesse exato sentido, importante colacionar a lição do Ministro Celso de Mello quando da admissão da Associação dos Magistrados Catarinenses como amicus curiae na $\mathrm{ADI} \mathrm{n}^{\circ} 2.130$ :

No estatuto que rege o sistema de controle normativo abstrato de constitucionalidade, o ordenamento positivo brasileiro processualizou a figura do amicus curiae (Lei $\mathrm{n}^{\circ}$ 9.868/99, art. $7^{\circ}, \S 2^{\circ}$ ), permitindo que terceiros - desde que investidos da representatividade adequada - possam ser admitidos na relação processual, para efeito de manifestação sobre a questão de direito subjacente à própria controvérsia constitucional. - A admissão de terceiro, na condição de amicus curiae, no processo objetivo de controle normativo abstrato, qualifica-se como fator de legitimação social das decisões da Suprema Corte, enquanto Tribunal Constitucional, pois viabiliza, em obséquio ao postulado democrático, a abertura do processo de fiscalização concentrada de constitucionalidade, em ordem a permitir que nele se realize, sempre sob uma perspectiva eminentemente pluralística, a possibilidade de participação formal de entidades e de instituições que efetivamente representem os interesses gerais da coletividade ou que expressem os valores essenciais e relevantes de grupos, classes ou estratos sociais. Em suma: a regra inscrita no art. $7^{\circ}, \S 2^{\circ}$, da Lei $n^{\circ} 9.868 / 99-$ que contém a base normativa legitimadora da intervenção processual do amicus curiae - tem por precípua finalidade pluralizar o debate constitucional. ${ }^{22}$ (destaques acrescidos)

E, na mesma linha, afirma o Ministro Gilmar Mendes:

(...) Essa construção jurisprudencial sugere a adoção de um modelo procedimental que ofereça alternativas e condições para permitir, de modo cada vez mais intenso, a interferência de uma pluralidade de sujeitos, argumentos e visões. Essa nova realidade pressupõe, além de amplo acesso e participação de sujeitos interessados no sistema de controle de constitucionalidade de normas, a possibilidade efetiva de o Tribunal Constitucional lançar mão de quaisquer das perspectivas disponíveis para a apreciação da legitimidade de um determinado ato questionado. (...) Entendo, portanto, que a admissão de amicus curiae confere ao processo um

\footnotetext{
${ }^{22}$ STF, ADI n ${ }^{\circ} 2.130$, decisão publicada no DJ, edição de 02/02/01, p. 145.
} 
Revista Eletrônica de Direito Processual - REDP.

Rio de Janeiro. Ano 11. Volume 18. Número 3. Setembro a Dezembro de 2017

Periódico Quadrimestral da Pós-Graduação Stricto Sensu em Direito Processual da UERJ

Patrono: José Carlos Barbosa Moreira. ISSN 1982-7636. pp. 256-279

www.redp.uerj.br

colorido diferenciado, emprestando-lhe caráter pluralista e aberto, fundamental para o reconhecimento de direitos e a realização de garantias constitucionais em um Estado Democrático de Direito. Assim, em face do art. $7^{\circ}, \S 2^{\circ}$, da Lei n\} 9.868/1999, defiro o pedido do Conselho Nacional de Chefes de Polícia Civil (CONCPC), para que possa intervir no feito, na condição de amicus curiae. ${ }^{23}$ (destaques acrescidos)

Em outro excerto de grande relevância, manifestou-se o Ministro Gilmar Mendes no sentido de a possibilidade de intervenção de terceiros, na modalidade de amicus curiae, ensejar a hipótese de o Tribunal decidir as causas com pleno conhecimento de todas as suas implicações ou repercussões: "trata-se de providência que confere caráter pluralista ao processo objetivo de controle abstrato de constitucionalidade".

Ainda sobre o tema, o Ministro Celso de $\mathrm{Mello}^{24}$, trazendo à lume o magistério de Gilmar Ferreira Mendes, mostra-nos a dimensão do papel exercido pelo amicus curiae no controle concentrado de constitucionalidade:

(...) Tenho presente, neste ponto, o magistério do eminente Ministro GILMAR MENDES ("Direitos Fundamentais e Controle de Constitucionalidade", p. 503/504, 2a ed., 1999, Celso Bastos Editor), expendido em passagem na qual põe em destaque o entendimento de PETER HÄBERLE, segundo o qual o Tribunal "há de desempenhar um papel de intermediário ou de mediador entre as diferentes forças com legitimação no processo constitucional" (p. 498), em ordem a pluralizar, em abordagem que deriva da abertura material da Constituição, o próprio debate em torno da controvérsia constitucional, conferindo-se, desse modo, expressão real e efetiva ao princípio democrático, sob pena de se instaurar, no âmbito do controle normativo abstrato, um indesejável "déficit" de legitimidade das decisões que o supremo tribunal federal venha a pronunciar no exercício, "in abstracto", dos poderes inerentes à jurisdição constitucional.

No mesmo texto, o Ministro Celso de Mello, referindo-se à importância da presença do amicus curiae, expõe o entendimento do Professor Inocêncio Mártires Coelho (“As

${ }^{23}$ STF, ADI no 3.494, decisão monocrática publicada no DJ, edição de 08/03/06.

${ }^{24}$ STF, ADI n ${ }^{\circ}$ 2.321-7, Min. Celso de Mello, em 25/10/2000. 
Revista Eletrônica de Direito Processual - REDP.

Rio de Janeiro. Ano 11. Volume 18. Número 3. Setembro a Dezembro de 2017

Periódico Quadrimestral da Pós-Graduação Stricto Sensu em Direito Processual da UERJ

Patrono: José Carlos Barbosa Moreira. ISSN 1982-7636. pp. 256-279

www.redp.uerj.br

ideias de Peter Harbele e a abertura da interpretação constitucional no direito brasileiro", IN RDA 211/125-134) ${ }^{25}$, qual seja:

Admitida, pela forma indicada, a presença do amicus curiae no processo de controle de constitucionalidade, não apenas se reitera a impessoalidade da questão constitucional, como também se evidencia que o deslinde desse tipo de controvérsia interessa objetivamente a todos os indivíduos e grupos sociais, até porque ao esclarecer o sentido da Carta Política, as cortes constitucionais, de certa maneira, acabam reescrevendo as constituições.

Não se pode negar que as alterações trazidas pela Carta Magna de 1988 ampliaram o rol dos entes legitimados para o controle concentrado de constitucionalidade. Contudo, o acesso limitado à jurisdição constitucional (o que restringe o debate constitucional às manifestações dos proponentes e demais partes constitucionalmente autorizadas), somado à eficácia erga omnes das decisões proferidas, gera um déficit de legitimação das decisões do Supremo Tribunal Federal, emitidas em sede de controle abstrato. A necessidade de superação desse déficit contribui para o crescente alargamento da participação dos amicus curiae no controle da constitucionalidade. ${ }^{26}$

Em outras palavras, para os assuntos em que haja controvérsias sobre controle da constitucionalidade, deve haver uma resolução derivada de profundos exames sobre o assunto e que sejam capazes de comprovar a extinção de qualquer dúvida suscitada sobre o caso. Eis a extrema relevância da figura do amicus curiae, dada a sua colaboração na obtenção de uma decisão madura e segura.

Isto posto, pode-se considerar que a figura do amicus curiae é mais que uma simples intervenção formal no processo e sua atuação ultrapassa a apresentação de memoriais ou o atendimento de simples informações que lhe sejam solicitadas, pois tem legitimidade para mais exercícios no âmbito processual, tecendo considerações, contribuindo com suas iniciativas e atuando com qualidades diversas das usualmente

\footnotetext{
${ }^{25}$ Idem.

${ }^{26}$ De forma bastante elucidativa, manifestou-se Edgar Silveira Bueno Filho, ao aduzir o quanto segue: (...) E, havendo dúvida sobre a constitucionalidade, é necessária, para garantir a segurança jurídica e a coerência do sistema, a solução do conflito. Se determinado ato normativo provoca dúvidas quanto a esse importante aspecto de sua validade, a ponto de justificar a movimentação das pessoas constitucionalmente designadas para exercer o processo de controle, nada melhor do que esmiuçá-lo, de forma exaustiva, de modo a se obter uma decisão mais segura e completa possível. (BUENO FILHO, Edgar Silveira. Amicus Curiae - A Democratização do Debate nos Processos de Controle da Constitucionalidade, in: Revista Diálogo Jurídico, n. 14, junho/agosto, Salvador, 2002). [itálico nosso].
} 
Revista Eletrônica de Direito Processual - REDP.

Rio de Janeiro. Ano 11. Volume 18. Número 3. Setembro a Dezembro de 2017

Periódico Quadrimestral da Pós-Graduação Stricto Sensu em Direito Processual da UERJ

Patrono: José Carlos Barbosa Moreira. ISSN 1982-7636. pp. 256-279

www.redp.uerj.br

ocupadas pelos "terceiros-intervenientes", visando à elevada qualidade da decisão a ser proferida pelo Supremo Tribunal Federal.

Nesse diapasão, o Ministro Gilmar Mendes, em sua obra Curso de Direito Constitucional, em coautoria com Inocêncio Mártires Coelho e Paulo Gustavo Gonet Branco, pontificou que:

(...) quanto à atuação do amicus curiae, após ter entendido que ela haveria de limitar-se à manifestação escrita, houve por bem o Tribunal admitir sustentação oral por parte desses peculiares partícipes do processo constitucional. Em 30-32004 foi editada Emenda Regimental (Emenda Regimental $\mathrm{n}^{\circ}$ 15 do STF, com base nos julgamentos ADI-QO 2.675, Rel. Carlos Velloso e ADI-QO 2.777, Rel. Cezar Peluso), que assegurou aos amici curiae, no processo de ADI, o direito de sustentar oralmente pelo tempo máximo de quinze minutos e, ainda, quando houver litisconsortes não representados pelo mesmo advogado, pelo prazo contado em dobro. ${ }^{27}$

Saudável e fundamental, portanto, para o debate democrático, que a sociedade civil organizada, por meio de entidades representativas e nas questões relevantes, compareça perante esse egrégio Tribunal e participe do processo de controle concentrado de constitucionalidade, ampliando e enriquecendo o debate acerca da questão constitucional controvertida.

A jurisprudência da Suprema Corte brasileira assentou-se no sentido de permitir o ingresso do amicus curiae, mesmo quando escoado o prazo de trinta dias para a apresentação das informações.

O Ministro Cezar Peluso assim afirmou:

(...) a admissão da figura do amicus curiae, tradicional no sistema da commom law, constitui evidente manifestação do impacto que o julgamento de ação de controle concentrado de constitucionalidade produz sobre a ordem jurídica social. (...) abre-se um canal valioso para a participação de membros do corpo social interessados no processo de tomada de decisão da Corte, em reforço da legitimidade e do caráter plural e democrático da atividade exercida pelo julgador. ${ }^{28}$

\footnotetext{
${ }^{27}$ MENDES, Gilmar Ferreira, COELHO, Inocêncio Mártires e BRANCO, Paulo Gustavo Gonet. Curso de Direito Constitucional. $1^{\mathrm{a}}$ edição. São Paulo: Editora Saraiva, 2007, p. 1070.

${ }^{28}$ STF, ADI 3.474, rel. min. Cezar Peluso, acórdão de 13/10/05, publicado no DJ, edição de 19/10/05, p. 32.
} 
Revista Eletrônica de Direito Processual - REDP.

Rio de Janeiro. Ano 11. Volume 18. Número 3. Setembro a Dezembro de 2017

Periódico Quadrimestral da Pós-Graduação Stricto Sensu em Direito Processual da UERJ

Patrono: José Carlos Barbosa Moreira. ISSN 1982-7636. pp. 256-279

www.redp.uerj.br

E nessa esteira, revendo posicionamento anterior, proferiu voto no sentido de permitir o ingresso de entidade como amicus curiae, mesmo após o referido prazo. De igual forma manifestou-se o Ministro Gilmar Mendes no julgamento da ADI $n^{\circ} 2.548^{29}$. Nesse mesmo sentido, ao citar o julgamento da ADI $n^{\circ} 2.238 / \mathrm{DF}$, em que foi relator o Ministro Ilmar Galvão, o Ministro Gilmar Mendes cogita da admissão de amicus curiae fora do prazo das informações (art. $\left.9^{\circ}, \mathrm{I}\right)$, especialmente diante da relevância do caso ou, ainda, em face da notória contribuição que a manifestação possa trazer para o julgamento da causa.

De qualquer sorte, não se admite o ingresso do amicus uma vez que já tenha, o processo, sido incluído em pauta. Nesse sentido é iterativa a jurisprudência do Supremo Tribunal Federal (Cf. ADI nº 2435 AgR/RJ; ADI n 4071 AgR/DF; ACU nº 779 AgR/RJ).

Traçados os contornos gerais de sua aplicação nas ações de controle concentrado e abstrato de constitucionalidade, impõe-se seguir em frente, examinando-se o regramento trazido pelo atual Novo $\mathrm{CPC}$, que, nitidamente, conferiu notável abertura às hipóteses de cabimento que comportam a atuação do amicus curiae, de modo a permitir que o instituto seja invocado em todos os processos judiciais.

\section{O AMICUS NO NOVO CÓDIGO DE PROCESSO CIVIL (LEI No 13.105/15)}

O Novo Código de Processo Civil conferiu notoriedade ao instituto jurídico do amicus curiae, na medida em que dedicou capítulo próprio, no bojo do Título III (Da intervenção de terceiros) do Livro III, relativo aos sujeitos processuais. Neste passo, podese considerar uma sensível inovação, na medida em que passou a disciplinar a aplicação do instituto de modo genérico de uma figura que, aqui e ali, já tinha sua participação prevista (como, por exemplo, nos casos de controle abstrato de constitucionalidade - Lei $\mathrm{n}^{\circ}$ 9.868/99; na Lei do CADE e na análise da repercussão geral pelo Supremo Tribunal Federal - art. 543-A, $\left.\S 3^{\circ}, \mathrm{CPC} / 73\right) .{ }^{30}$

\footnotetext{
${ }^{29}$ STF, ADI 2.548, rel. min. Gilmar Mendes, decisão monocrática publicada no DJ, edição de 24/10/05.

30 “A previsão de ampla participação de amici curiae é de especial relevância, porque reconhece a importância da dimensão participativa no processo por meio de um importante instrumento de atuação política e social, consagrando mais um espaço de participação democrática no Estado de Direito.
} 
Revista Eletrônica de Direito Processual - REDP.

Rio de Janeiro. Ano 11. Volume 18. Número 3. Setembro a Dezembro de 2017

Periódico Quadrimestral da Pós-Graduação Stricto Sensu em Direito Processual da UERJ

Patrono: José Carlos Barbosa Moreira. ISSN 1982-7636. pp. 256-279

www.redp.uerj.br

Ao lado do regramento geral contido no artigo 138, o Novo CPC foi cuidadoso e previu, particularmente, hipóteses específicas de aplicação da intervenção do amicus

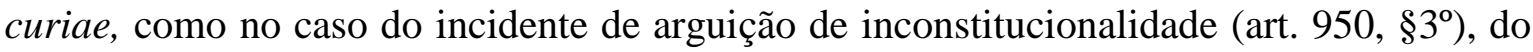
incidente de resolução de demandas repetitivas (art. 983, $§ 1^{\circ}$ ), da definição da repercussão geral (art. 1.035, $\S 4^{\circ}$ ) e da análise de recursos repetitivos (art. 1.038, II).

Em um primeiro momento, seria possível concluir que o novel regramento processual pareceu assentar seu posicionamento quanto a natureza jurídica do amicus curiae, na medida em que o incluiu como espécie do gênero intervenção de terceiros e do subgênero assistência litisconsorcial, ao lado de outros institutos como denunciação da lide, chamamento ao processo e incidente de desconsideração da personalidade jurídica. Temos para nós, porém, não ter sido essa a melhor escolha do legislador.

De qualquer sorte, é digna de aplausos a sua previsão e disciplina, pelo Novo CPC, e a ênfase que se dá ao instituto, de molde a permitir - uma vez presentes seus pressupostos - da maneira mais genérica possível, a intervenção da figura do amicus curiae nas causas não penais ou nas que, ainda que subsidiariamente, apliquem-se as disposições do CPC. Em sendo assim, convém ter presente a redação do art. 138, in verbis:

Art. 138. O juiz ou relator, considerando a relevância da matéria, a especificidade do tema objeto da demanda ou a repercussão social da controvérsia, poderá, por decisão irrecorrível, de ofício ou a requerimento das partes ou de quem pretenda manifestar-se, solicitar ou admitir a participação de pessoa natural ou jurídica, órgão ou entidade especializada, com representatividade adequada no prazo de 15 (quinze) dias de sua intimação.

§1. A intervenção de que trata o caput não implica alteração de competência nem autoriza a interposição de recursos, ressalvadas a oposição de embargos de declaração e a hipótese do $\S 3^{\circ}$.

$\S 2 .^{\circ}$ Caberá ao juiz ou ao relator, na decisão que solicitar ou admitir a intervenção, definir os poderes do amicus curiae.

§3. ${ }^{\circ} \mathrm{O}$ amicus curiae pode recorrer da decisão que julgar o incidente de resolução de demandas repetitivas.

Diante desse cenário, é possível vislumbrar a presença de três requisitos alternativos que haverão de comparecer para que se justifique a participação do amicus

(CARNEIRO, Paulo Cezar Pinheiro; PINHO, Humberto Dalla Bernardina de. Novo Código de Processo Civil Anotado e Comparado. 2. Ed. Rio de Janeiro: Forense, 2017, p. 79) 
Revista Eletrônica de Direito Processual - REDP.

Rio de Janeiro. Ano 11. Volume 18. Número 3. Setembro a Dezembro de 2017

Periódico Quadrimestral da Pós-Graduação Stricto Sensu em Direito Processual da UERJ

Patrono: José Carlos Barbosa Moreira. ISSN 1982-7636. pp. 256-279

www.redp.uerj.br

curiae naquela determinada demanda: a relevância da matéria, a especificidade do tema

objeto da demanda e a repercussão social. São considerados requisitos independentes, donde a presença de apenas um deles, por si só, já justifica a intervenção do instituto. ${ }^{31}{ }^{32}$

No que tange ao requisito da relevância da matéria, observa-se, segundo Teresa Arruda Alvim Wambier et al, o mesmo fenômeno evidenciado no caso da repercussão geral do recurso extraordinário, qual seja a utilização de conceitos vagos por parte do legislador ordinário, que acaba por ocasionar a necessidade de que a doutrina e jurisprudência "se empenhem no sentido de identificá-los, ainda que não de forma rígida, pois isto engessaria as possibilidades do uso do instituto". 33

$\mathrm{O}$ artigo $1.035, \S 1^{\circ}$ do $\mathrm{CPC}$ determina que se considera presente a repercussão geral nos casos de existência de "questões relevantes do ponto de vista econômico, político, social ou jurídico, que ultrapassem os interesses subjetivos do processo". A partir disso, é possível seguir o mesmo entendimento para o caso de relevância da matéria no bojo do amicus curiae, de modo a ser necessário que a matéria extravase o âmbito das discussões individuais firmadas entre as partes, ou seja, a questão jurídica envolvida deve sobrepujar o interesse individual, tendo relevância do ponto de vista coletivo.

A necessidade de especificidade do tema relaciona-se com o interesse institucional por parte do legitimado a intervir como amicus curiae. Deste modo, diante da complexidade do objeto da demanda, a necessidade de conhecimentos de ordem específica, técnicos ou científicos, impõe que haja uma representatividade adequada entre a missão institucional atribuída ao legitimado e o objeto da demanda. Logo, a sua admissão no processo judicial está condicionada à possibilidade de efetiva contribuição para o aspecto qualitativo do debate em pauta, pois que o interesse institucional do qual é portador o legitimado deve se relacionar diretamente com a matéria em litígio.

Por fim, é de ressaltar que o requisito da repercussão social se atrela ao supramencionado requisito da relevância da matéria, uma vez que define ser imprescindível que a questão jurídica tenha reflexos não só na relação intersubjetiva alvo

${ }^{31}$ WAMBIER, Teresa Arruda Alvim et al. Primeiros comentários ao Novo Código de Processo Civil. 2 ed. São Paulo: Editora Revista dos Tribunais, 2016. p. 293.

${ }^{32}$ Assim, recentemente chancelou o STF que "Conforme o art. 138 do CPC/15, os critérios para admissão de entidades como amicus curiae são a relevância da matéria, especificidade do tema ou repercussão social da controvérsia, assim como a representatividade adequada do pretendente." (RE 705423 AgR-segundo/SE, Relator(a): Min. EDSON FACHIN, Julgamento: 15/12/2016, Órgão Julgador: Tribunal Pleno, Publicação, DJe-024 DIVULGADO 07-02-2017 PUBLICADO 08-02-2017).

${ }^{33}$ WAMBIER, Teresa Arruda Alvim et al. Op. Cit. p. 294. 
Revista Eletrônica de Direito Processual - REDP.

Rio de Janeiro. Ano 11. Volume 18. Número 3. Setembro a Dezembro de 2017

Periódico Quadrimestral da Pós-Graduação Stricto Sensu em Direito Processual da UERJ

Patrono: José Carlos Barbosa Moreira. ISSN 1982-7636. pp. 256-279

www.redp.uerj.br

de discussão, mas em toda a coletividade, seja do ponto de vista econômico, social, político ou jurídico.

Aspectos relevantes também podem ser destacados quanto à delimitação do âmbito da legitimidade e da competência trazidos pelo Novo CPC.

Em primeiro plano, há que se ter presente que a intervenção do amicus pode-se dar tanto por requerimento daquele que pretende atuar nessa condição quanto poderá, essa convocação, dar-se de ofício, pelo juiz ou relator, em qualquer instância ou tribunal.

No que interessa à legitimidade, o Novo CPC acabou por dirimir a dúvida até então existente, acerca da admissão - ou não - da intervenção de pessoa natural na qualidade amicus curiae. E assim o fez colocando essa específica hipótese ao lado da possibilidade de manifestação da pessoa jurídica, de órgãos ou entidades especializadas. Destaca-se, que na condição de terceiro legitimado não se admite a intervenção de quem já integra a lide como parte principal - é possível que a parte requeira a participação do amicus curiae, sem, contudo, poder atuar como amicus curiae -, ademais, o caput do artigo 138 permite que o juiz ou o relator, de ofício, manifestem-se no sentido de necessidade da intervenção do amigo da corte.

No que se refere à competência, o artigo 138 , parágrafo $1^{\circ}$ define que a participação do amicus curiae não importa em alteração de competência, é dizer, mesmo que seja hipótese, por exemplo, de intervenção de órgão ou entidade federal em processo de competência estadual, não restará deslocada a competência para a Justiça Federal.

Quanto à esfera de atuação do amicus curiae, convém notar não lhe ser permitida a prática de atos processuais que se sobrepujem a sua manifestação a respeito da questão jurídica em debate e suas consequentes repercussões. Ou seja, a intervenção do amicus curiae é considerada restrita, até mesmo diante da hipótese de assistência simples - razão que corrobora com o já aludido entendimento de que o amicus curiae não poderia ser considerado uma intervenção de terceiro típica.

No âmbito do controle de constitucionalidade o STF já havia decidido que o amicus podia fazer sustentação oral, bem como apresentar memoriais, mas não the era dado o direito de recorrer. 
Revista Eletrônica de Direito Processual - REDP.

Rio de Janeiro. Ano 11. Volume 18. Número 3. Setembro a Dezembro de 2017

Periódico Quadrimestral da Pós-Graduação Stricto Sensu em Direito Processual da UERJ

Patrono: José Carlos Barbosa Moreira. ISSN 1982-7636. pp. 256-279

www.redp.uerj.br

$\mathrm{Na}$ disciplina do Novo CPC, resta clara a vedação a que os amici curiae recorram, conforme disposição contida no parágrafo $1^{\circ}$ do artigo $138^{34}$, excetuadas, porém, duas hipóteses de legitimidade recursal: a possibilidade de opor embargos declaratórios e a hipótese contida no parágrafo $3^{\circ}$ do mesmo dispositivo, quanto a interposição de recurso contra decisão que julga incidente de resolução de demandas repetitivas. Do mesmo modo, considera-se irrecorrível a decisão que admite o amicus curiae e a que determina, de ofício, sua integração na relação processual, previsão amplamente criticada por Cássio Scarpinella Bueno. $^{35}$

Quanto aos poderes do amicus curiae, o parágrafo $2^{\circ}$ do artigo 138 define que caberá ao juiz ou ao relator defini-los, donde se conclui que - salvo melhor juízo - a decisão que defere o pedido de intervenção ou a determina, já deverá contemplar e demarcar os poderes aos quais estará condicionada a atuação do amicus, considerando a utilidade da intervenção. Cabe ressaltar, que, por óbvio, aludida delimitação de poderes não pode ser discutida no bojo de eventual recurso, uma vez que, conforme antes mencionado, as hipóteses recursais foram previamente definidas pelo legislador.

Não é possível deixar de ressaltar a relevância do amicus curiae para a expansão do princípio do contraditório, ainda mais perceptível no caso dos processos que apreciam demandas de massa, de natureza repetitiva e que veiculam decisões com eficácia de precedente vinculante. É o que se encontra nos aludidos casos em que o CPC disciplinou o emprego específico do instituto do amicus curiae, qual sejam na hipótese de incidente de arguição de inconstitucionalidade, no incidente de resolução de demandas repetitivas e nos recursos especiais e extraordinários repetitivos. Ocorre, que por serem proferidas decisões judiciais com eficácia vinculante, resta latente a necessidade de uma maior legitimação democrática, por via de um contraditório que seja ampliado, fruto de uma participação de

\footnotetext{
${ }^{34}$ No âmbito das ações de controle de constitucionalidade, é firme e iterativa a jurisprudência no sentido de inadmitir interposição de recursos pelo amicus curiae, conforme se extrai da seguinte ementa: "Agravo regimental no recurso extraordinário com agravo. Insurgência oposta pelo amicus curiae admitido nos autos. Inadmissibilidade. Posição processual que não lhe permite interpor recursos contra as decisões proferidas no respectivo processo. 1. É pacífica a jurisprudência desta Corte no sentido de que o amicus curiae, conquanto regularmente admitido nos autos, carece de legitimidade para a interposição de recursos nas ações de controle concentrado de constitucionalidade. 2. Agravo regimental a que se nega provimento." (STF, ARE 857753 AgR/MG, Relator(a): Min. Dias Toffoli, Órgão Julgador: Segunda Turma, publicação: DJe 105, Divulgado: 19.05.2017, Publicado: 22.05.2017) [grifos e destaques nossos]

${ }^{35}$ Cássio Scarpinella Bueno, Novo Código de Processo Civil Anotado. 3. ed. São Paulo: Saraiva, 2017, p. 195.
} 
Revista Eletrônica de Direito Processual - REDP.

Rio de Janeiro. Ano 11. Volume 18. Número 3. Setembro a Dezembro de 2017

Periódico Quadrimestral da Pós-Graduação Stricto Sensu em Direito Processual da UERJ

Patrono: José Carlos Barbosa Moreira. ISSN 1982-7636. pp. 256-279

www.redp.uerj.br

toda sociedade civil e do Estado, sendo o amicus curiae o instrumento capaz de efetivar a concretização do postulado democrático nos processos de litigância de massa.

\section{O AMICUS CURIAE, O NOVO CPC E A EFETIVAÇÃO DO ESTADO DEMOCRÁTICO DE DIREITO}

A figura do amicus curiae é, sem sombra de dúvida, um dos grandes instrumentos e mecanismos de ampliação democrática do debate e de qualificação da tutela jurisdicional prestada. Como já reconheceu o Supremo Tribunal Federal:

“(...) $\mathrm{O}$ ordenamento positivo brasileiro processualizou, na regra inscrita no art. $7^{\circ}, \S 2^{\circ}$, da Lei $n^{\circ} 9.868 / 99$, a figura do "amicus curiae", permitindo, em consequência, que terceiros, desde que investidos de representatividade adequada, sejam admitidos na relação processual, para efeito de manifestação sobre a questão de direito subjacente à própria controvérsia constitucional. A intervenção do 'amicus curiae', para legitimar-se, deve apoiar-se em razões que tornem desejável e útil a sua atuação processual na causa, em ordem a proporcionar meios que viabilizem uma adequada resolução do litígio constitucional. - A ideia nuclear que anima os propósitos teleológicos que motivaram a formulação da norma legal em causa, viabilizadora da intervenção do 'amicus curiae' no processo de fiscalização normativa abstrata, tem por objetivo essencial pluralizar o debate constitucional, permitindo, desse modo, que o Supremo Tribunal Federal venha a dispor de todos os elementos informativos possíveis e necessários à resolução da controvérsia, visando-se, ainda, com tal abertura procedimental, superar a grave questão pertinente à legitimidade democrática das decisões emanadas desta Suprema Corte, quando no desempenho de seu extraordinário poder de efetuar, em abstrato, o controle concentrado de constitucionalidade."

Neste ambiente, o regramento trazido pelo Novo CPC e frente a toda lógica democrática que compõe o fundamento da atuação do amicus curiae, é possível enxergar a necessidade de que a prestação jurisdicional, e a consequente decisão judicial, espelhem, cada vez mais, a vontade da sociedade civil e os valores adotados pela Constituição 
Revista Eletrônica de Direito Processual - REDP.

Rio de Janeiro. Ano 11. Volume 18. Número 3. Setembro a Dezembro de 2017

Periódico Quadrimestral da Pós-Graduação Stricto Sensu em Direito Processual da UERJ

Patrono: José Carlos Barbosa Moreira. ISSN 1982-7636. pp. 256-279

www.redp.uerj.br

Federal. Logo, a intenção do CPC ao autorizar a implementação do amicus curiae em

todos as ações e momentos processuais foi de implantar um processo mais cooperativo, que busca, em última medida a verdade real.

Cândido Rangel Dinamarco e Bruno Vasconcelos Carrilho Lopes exaltam, a esse respeito, que o legislador teve, claramente, a "sadia intenção de ampliar e enriquecer as discussões das causas mediante a participação de entes especializados e representativos supostamente aptos a auxiliar os juízes na boa compreensão das questões”36 e, em última instância, auxiliando na melhoria da prestação jurisdicional. Nessa medida, incrementando a qualidade das decisões judiciais, realizam-se, em sua plenitude, as garantias do devido processo legal e do acesso à justiça.

De fato, intervenção do amicus curiae no bojo do processo em geral constitui, para nós, um dos muitos instrumentos utilizados pelo Novo CPC para a democratização do processo judicial. ${ }^{37}$ Ao que tudo indica, não se coaduna mais com os novos paradigmas do sistema processual uma estrutura e uma visão privatista - e quiçá autoritária - do processo, conduzido sob a forma de monopólio pelo magistrado. Por via de uma visão comparticipativa, é necessário o amplo diálogo dos juízes, das partes, da sociedade civil em geral para a construção, conjunta, do resultado final do processo, que, em última análise, é mecanismo de realizar e concretizar os direitos fundamentais consagrados pela Constituição Federal.

\section{CONCLUSÃO}

A partir deste breve ensaio, é possível concluir que o regramento do amicus curiae trazido pelo novo CPC representa um importante instrumento de valorização da jurisdição democrática, na medida em que possibilita a participação ativa da sociedade em todas as instâncias de julgamento, permitindo o enriquecimento do debate entre os envolvidos e

\footnotetext{
${ }^{36}$ DINAMARCO, Cândido Rangel; LOPES, Bruno Vasconcelos Carrilho. Teoria Geral do Novo Processo Civil. 2 ed. São Paulo: Malheiros, 2017, p. 164.

37 Adhemar Ferreira Maciel, confirma nossas conclusões: "O amicus curiae é um instituto de matiz democrático, uma vez que permite, tirando um ou outro caso de nítido interesse particular, que terceiros penetrem no mundo fechado e subjetivo do processo para discutir objetivamente teses jurídicas que vão afetar toda a sociedade." ("Amicus Curiae”: um instituto democrático. Revista de Informação Legislativa. Brasília, ano 38, n. 153, jan./mar.2002, p. 7).
} 
Revista Eletrônica de Direito Processual - REDP.

Rio de Janeiro. Ano 11. Volume 18. Número 3. Setembro a Dezembro de 2017

Periódico Quadrimestral da Pós-Graduação Stricto Sensu em Direito Processual da UERJ

Patrono: José Carlos Barbosa Moreira. ISSN 1982-7636. pp. 256-279

www.redp.uerj.br

valorizando o Estado Democrático de Direito, em questões de grande interesse social e relevância coletiva.

Anteriormente adstrito à hipóteses específicas, tais como as do processo objetivo de controle de constitucionalidade, com o advento do Novo CPC, o amicus curiae passou a ser admitido em qualquer processo judicial, em significativo processo de abertura aos valores democráticos defendidos pela Constituição Federal de 1988, corroborando de forma positiva para a formação da convicção do magistrado diante da complexidade das demandas atuais.

De igual modo, na medida em que o CPC atual determinou, de forma específica, a possibilidade de aplicação da figura do amicus curiae no julgamento dos casos repetitivos, houve a preocupação em se garantir maior participação àqueles que, em momento posterior, irão suportar os efeitos de uma eventual decisão proferida, haja vista que os precedentes judiciais de lides seriadas possuem eficácia vinculante. Diante dessas hipóteses, assegura-se larga democratização das decisões judiciais, com participação plural decisiva da sociedade, afastando-se, na mesma proporção, do engessamento jurisprudencial que poderia ocorrer.

A partir do que foi demostrado no bojo desta pesquisa, foi possível analisar que o artigo 138 do CPC trouxe um regramento mais claro do que aquele contido, por exemplo, na Lei $n^{\circ}$ 9.868/99, definindo seus requisitos, legitimados e até uma regra de competência, contudo, é certo que muitas dúvidas ainda irão pairar no tocante à aplicação do instituto, questionamentos estes que só serão respondidos diante da provocação do Judiciário. É o que provavelmente irá ocorrer, à título de exemplificação, com o §2 do artigo 138, uma vez que ao dispor que "caberá ao juiz ou ao relator, na decisão que solicitar ou admitir a intervenção, definir os poderes do amicus curiae”, conferiu amplo grau de discricionariedade, o qual deverá ter seus contornos delimitados pelos órgãos judiciais diante dos casos concretos, a fim de não conferir margem à arbitrariedade na atuação jurisdicional.

Inobstante a essa observação, não se pode olvidar a nobre intenção do legislador ordinário, na medida em que possibilitou aos jurisdicionados a intervenção na qualidade da decisão judicial, desde que preenchidos os requisitos legais, ampliando a participação democrática no bojo do processo, bem como, nitidamente contribuindo para a busca da efetividade e celeridade processual. 
Revista Eletrônica de Direito Processual - REDP.

Rio de Janeiro. Ano 11. Volume 18. Número 3. Setembro a Dezembro de 2017

Periódico Quadrimestral da Pós-Graduação Stricto Sensu em Direito Processual da UERJ

Patrono: José Carlos Barbosa Moreira. ISSN 1982-7636. pp. 256-279

www.redp.uerj.br

É certo que o direito e o sistema processual como um todo não podem viver

vinculados a um modelo estático de regras jurídicas, alheio à sociedade, sendo necessário um movimento constante de comunicação com o "mundo dos fatos" e os anseios sociais, de forma a alcançar uma decisão que seja justa, equânime, razoável e eficaz para a comunidade em geral. Deste modo, a construção do ordenamento jurídico deve sempre priorizar instrumentos que viabilizem a participação social nas deliberações judiciais, como acontece na estruturação do amicus curiae.

Trata-se de medida que poderá promover mudança cultural e comportamental relevante no processo de acesso à justiça e de sua respectiva distribuição, aproximando o anseio por resolução de controvérsias jurídicas à uma técnica que permite pontuar a dimensão coletiva de conflitos localizados ou individuais. De igual forma, proporcionará ao Poder Judiciário a possibilidade de integrar em sua atuação os elementos legitimadores dos amici curiae, em um processo de constante vivificação da letra da lei e de sua aplicação junto ao jurisdicionado.

Isto posto, conclui-se que uma aplicação do direito por parte dos magistrados e Tribunais que seja descompromissada com a realidade social não se coaduna com os ideais preconizados pela Constituição Federal de 1988, bem como com o novo perfil de processo civil constitucional. Os valores constitucionais democráticos de comparticipação e de pluralização devem ser desenvolvidos diante do contexto atual, objetivando a construção e a consolidação da cidadania democrática e participativa, a partir de espaços públicos, inclusive dentro dos processos judiciais, que permitam a deliberação e manifestação dos interesses sociais dos mais diversos grupos envolvidos, o que, em última escala, permitirá a evolução da própria sociedade.

\section{REFERÊNCIAS BIBLIOGRÁFICAS:}

BUENO, Cassio Scarpinella. Amicus Curiae no Processo Civil Brasileiro - um terceiro enigmático. 3. ed. São Paulo: Saraiva, 2012.

Novo código de processo civil anotado. 3. ed. São Paulo: Saraiva, 2016.

BUENO FILHO, Edgar Silveira. Amicus Curiae - A Democratização do Debate nos

Processos de Controle da Constitucionalidade, in: Revista Diálogo Jurídico, n. 14, junho/agosto, Salvador, 2002. 
Revista Eletrônica de Direito Processual - REDP.

Rio de Janeiro. Ano 11. Volume 18. Número 3. Setembro a Dezembro de 2017

Periódico Quadrimestral da Pós-Graduação Stricto Sensu em Direito Processual da UERJ

Patrono: José Carlos Barbosa Moreira. ISSN 1982-7636. pp. 256-279

www.redp.uerj.br

CAMBI, Eduardo. Neoconstitucionalismo e Neoprocessualismo - Direitos fundamentais, políticas públicas e protagonismo judiciário. São Paulo: RT, 2009.

- Neoconstitucionalismo e neoprocessualismo. Revista Panoptica - Direito,

Sociedade e Cultura. Ano 1, n. 6, número 6. Disponível em:

<http://www.panoptica.org/seer/index.php/op>. Acesso em 31.05.2017.

CARNEIRO, Paulo Cezar Pinheiro. In: WAMBIER, Teresa Arruda Alvim et al (Coords.).

Breves comentários ao Novo Código de processo civil. São Paulo: Revista dos Tribunais, 2015.

CARVALHO E SILVA, Fernando Gabriel de. Amicus curiae no Novo Código de Processo Civil. Rio de Janeiro: Editora Lumen Juris, 2016.

COUTO, Mônica Bonetti; MEYER-PFLUG; Samantha Meyer. Processo Civil e Constituição: uma $(\mathrm{Re})$ aproximação necessária. Processo e Jurisdição. Organização: CONPEDI/UFF. Coordenadores: Vladmir Oliveira da Silveira; Aires José Rover. Florianópolis, FUNJAB, 2012, pp. 411-433. $<$ http://www.publicadireito.com.br/artigos/?cod=173f0f6bb0ee97cf $>$. Acesso em 25.05.2017.

DIDIER JÚNIOR, Fredie Didier. Recurso de terceiro: juízo de admissibilidade. 2. ed. São Paulo: RT, 2005.

Possibilidade de Sustentação Oral do Amicus Curiae. Revista Dialética de Direito Processual 8, 2003.

DINAMARCO, Cândido Rangel; LOPES, Bruno Vasconcelos Carrilho. Teoria Geral do Novo Processo Civil. 2 ed. São Paulo: Malheiros, 2017.

MACIEL, Adhemar Ferreira. "Amicus Curiae”: um instituto democrático. Revista de Informação Legislativa. Brasília, ano 38, n. 153, jan./mar.2002, pp. 7-10.

MANCUSO, Rodolfo de Camargo. Acesso à justiça: condicionantes legítimas e ilegítimas.

2. ed. São Paulo: RT, 2016.

A resolução dos conflitos e a função judicial no contemporâneo Estado de direito. São Paulo: RT, 2009.

MEDINA, Damares. Amicus Curiae: Amigo da Corte ou Amigo da Parte? Saraiva, 2010.

MENDES, Aluisio Gonçaves de Castro; SILVA, Larrisa Clare Pochmann. Normas Fundamentais do Código de Processo Civil de 2015: breves reflexões. Revista Eletrônica de Direito Processual. V. 17, n. 2, jul/dez.2016. 
Revista Eletrônica de Direito Processual - REDP.

Rio de Janeiro. Ano 11. Volume 18. Número 3. Setembro a Dezembro de 2017

Periódico Quadrimestral da Pós-Graduação Stricto Sensu em Direito Processual da UERJ

Patrono: José Carlos Barbosa Moreira. ISSN 1982-7636. pp. 256-279

www.redp.uerj.br

MENDES, Gilmar Ferreira. Direitos Fundamentais e Controle de Constitucionalidade. 2. ed. Celso Bastos Editor, 1999.

; COELHO, Inocêncio Mártires e BRANCO, Paulo Gustavo Gonet. Curso de

Direito Constitucional. $1^{\text {a }}$ edição. São Paulo: Editora Saraiva, 2007.

NUNES, Dierle José Coelho. Processo Jurisdicional Democrático. $1^{\mathrm{a}}$ ed. Curitiba: Juruá, 2012.

OLIVEIRA, Vallisney de Souza. Constituição e Processo Civil. São Paulo: Saraiva, 2008.

PEREIRA, Milton Luiz. Amicus curiae - intervenção de terceiros. Revista de Processo, São Paulo, ano 28, v. 109, jan./mar. 2003, p. 39-44.

PINHO, Humberto Dalla Bernardina de. Os Princípios e as Garantias Fundamentais no Projeto de Código de Processo Civil: breves considerações acerca dos arts. $1 .^{\circ}$ a 13 do PL n. ${ }^{\circ}$ 166/10, Revista Eletrônica de Direito Processual, vol. VI, 2010, pp 49/92. Disponível em: 〈www.redp.com.br〉. Acesso em 21.05.2017.

SILVA, Fernando Laércio Alves da. Processo Constitucional: o processo como locus devido para o exercício da democracia. Revista Eletrônica de Direito Processual. V. 6, n. 16, jul/dez.2015.

THEODORO JÚNIOR, Humberto; NUNES, Dierle; BAHIA, Alexandre de Melo Franco; PEDRON, Flávio Quinaud. Novo CPC - Fundamentos e sistematização. Rio de Janeiro: Forense, 2015, p. 54.

TORRES, Artur. Constituição, Processo e Contemporaneidade: o modelo constitucional do processo brasileiro. Temas Atuais de Processo Civil, v. 1, p. 44-81, 2011. Disponível em:<Br/edicoes-anteriores/48-v-1-n2-agosto-de-2011/132-constituiçãoprocesso-e-contemporaneidade-o-modelo-constitucional-do-processo-brasileiro> Acesso em: 26 nov 2016.

WAMBIER, Teresa Arruda Alvim. Amicus curiae: afinal, quem é ele? Direito $e$ Democracia, Canoas, v. 8, n. 1, jan./jun. 2007.

et al. Primeiros comentários ao Novo Código de Processo Civil. 2 ed. São Paulo: Editora Revista dos Tribunais, 2016. p. 293.Processual Civil. 8 ed. Salvador: Editora JusPodivm, 2016.

ZANETI Jr, Hermes. Processo constitucional: o modelo constitucional do processo civil brasileiro. Rio de Janeiro: Lumen Juris, 2007. 